\title{
PENGGUNAAN EKSTRAK DAUN KATUK (Sauropus androgunus L. Merr) SEBAGAI BAHAN PENGAWET ALAMI DAGING AYAM
}

\section{THE USE OF KATUK LEAF EXTRACT (Sauropus androgunus L. Merr) AS A NATURAL PRESERVATIVE OF CHIKEN MEAT}

\author{
Bagus Hardianto, Rahma Hidaiyanti \\ Fakultas Pertanian, Universitas Dehasen \\ Email : rahma.kim86@gmail.com
}

\begin{abstract}
ABSTRAK
Bahan pengawet adalah bahan tambahan pangan yang dapat mencegah atau menghambat proses pembusukan yang disebabkan oleh mikroorganisme. Daging ayam merupakan salah satu bahan pangan yang mudah mengalami proses pembusukan. Penelitian ini bertujuan untuk menganalisis pengaruh perendaman daging ayam dalam ekstrak daun katuk terhadap $\mathrm{pH}$, kadar air, TPC dan uji organoleptik.

Penelitian dilakukan pada bulan Januari 2017 di Laboratorium Fakultas Pertanian Universitas Dehasen dan Laboratorium Kimia Universitas Bengkulu. Penelitian dilakukan dengan dua tahap yaitu perendaman daging ayam kedalam konsentrasi ekstrak daun katuk $(10 \%, 20 \%$ dan $30 \%)$ dan lama waktu perendaman 30 dan 60 menit, setelah itu ditiriskan dan daging ayam dibiarkan pada suhu ruang selama 12 jam, kemudian dilakukan pengujian $\mathrm{pH}$, kadar air, TPC dan uji organoleptik (warna, aroma dan tekstur).

Hasil penelitian menunjukkan bahwa perlakuan konsentrasi ekstrak daun katuk $30 \%$ dan waktu 30 menit adalah perlakuan terbaik dengan nilai $\mathrm{pH} 5,4$, kadar air 22, 35\% dan TPC $6 \times 10^{2} \mathrm{cfu} / \mathrm{g}$, namun tidak berpengaruh terhadap warna, aroma dan tekstur daging ayam.
\end{abstract}

KATA KUNCI : Daun Katuk (Sauropus adrogunus L. Merr), Daging Ayam, Pengawetan.

\section{ABSTRACT}

Preservatives are food additive that can prevent or inhibit the process of decomposition caused by microorganisms. Chicken meat is one food that is easy to experience the process of decay. This study aims to analyze the effect of immersion of chicken meat in katuk leaf extract to $\mathrm{pH}$, water content, TPC and organoleptic test.

The research was conducted in January 2017 at Dehasen University Laboratory and University Laboratory of Bengkulu. This research was done by making katuk leaf extract, after drained chicken meat leaf at room temperature for 12 hours, then tested the $\mathrm{pH}$, water content, TPC and organoleptik test (color, aroma and texture).

The research stages include preparation of katuk leaf extract with concentration of 10, 20 and 30\% with mixing of aquades as much as $200 \mathrm{~mL}$. The results showed that leaf extract concentration of $30 \%$ was the best treatment for the decrease of $\mathrm{pH}$, water content and TPC, but the concentration of katuk leaf extract did not affect the color, aroma and texture of chicken meat.

KEYWORDS : Leaf Katuk (Sauropus adrogunus L. Merr), chicken meat, Preservatives 


\section{PENDAHULUAN}

Dewasa ini, isu mengenai keamanan pangan terkait dengan adanya Bahan Tambahan Pangan (BTP), khususnya pengawet, menjadi semakin diperhatikan. Penggunaan bahan pengawet memiliki keuntungan dan kerugian. Di satu sisi dengan adanya pengawet, bahan makanan dapat dibebaskan dari aktivitas mikrobia baik yang bersifat patogen maupun yang menyebabkan kerusakan bahan pangan. Bahan pengawet pada dasarnya adalah senyawa kimia yang merupakan bahan asing yang akan masuk bersama makanan. Penggunaan bahan pengawet bila dosisnya tidak diatur, akan menimbulkan kerugian bagi pemakainya baik secara langsung maupun yang bersifat akumulatif (Cahyadi, 2009).

Daging ayam merupakan salah satu bahan pangan yang banyak digemari oleh masyarakat dari berbagai tingkatan ekonomi, karena selain harganya murah dibandingkan dengan harga daging yang lain (sapi, kerbau, kambing), daging ayam juga mengandung zat gizi yang sangat baik bagi tubuh. Daging ayam juga merupakan bahan pangan yang sangat mudah rusak (perishable). Kerusakan yang terjadi berkaitan erat dengan aktivitas mikroorganisme, sehingga untuk mencegah terjadinya pembusukan yang cepat, maka salah satunya dilakukan pengawetan dengan menggunakan ekstrak daun katuk sebagai bahan pengawetnya. Berbagai cara telah dilakukan untuk menjaga kualitas dan umur simpan daging ayam, salah satunya dengan menggunakan pengawet alami yang mudah didapat, terjangkau oleh masyarakat dan tidak menimbulkan dampak negatif terhadap kesehatan (Muhtadi dan Sugiono, 1992). Bahan pengawet alami tersebut salah satunya berasal dari ekstrak daun katuk (Saurupus androgunus L. Merr).

Ekstrak daun katuk mengandung senyawa bersifat anti bakteri. Beberapa kandungan dalam tanaman katuk bersifat bakteriosida yang dapat membunuh bakteri antara lain asam seskuitema, alkaloid papaverin, tanin, saponin, flavonoid, garam mineral dan minyak atsiri (Rukmana dan Harahap, 2003). Selain ltu, Pusat Penelitian dan Pengembangan (Puslitbang) Biologi LIPI menemukan tiga senyawa utama daun katuk yaitu cis-2-metil-siklopentanol asetat, 2pirilidion dan metil piroglutamat serta satu senyawa minor p-dodesifenol. Pada tahun yang sama Muehsin Darise dan Sulaeman melakukan penelitian lanjutan yang menunjukkan bahwa pada ekstrak daun katuk ditemukan zat penghambat pertumbuhan bakteri Staphylococcus aureus, Salmonella thyposa dan Eschericia coli.

\section{METODE PENELITIAN}

\section{Bahan dan Alat}

Bahan yang digunakan dalam penelitian adalah daging ayam segar yang dibeli di pasar Panorama Bengkulu, daun katuk segar (Sauropus androgonus L. Mer) dan aquades.

Alat-alat yang digunakan pada penelitian ini meliputi steroform, plastik, baskom, botol aqua bekas, saringan, nampan kecil, talenan, pisau, pinset, gunting, alumunium foil, magnet stirrer, kertas label, 
kapas, kertas saring, plastik wrapping, form penilaian organoleptik, dan alat-alat analisis yang meliputi gelas piala, gelas ukur, tabung reaksi.

\section{Cara Penelitian}

Aplikasi pengawetan ekstrak daun katuk pada daging ayam segar dilakukan melalui empat tahap, yaitu tahap persiapan, tahap perendaman, penyimpanan dan tahap pengujian.

\section{Tahap Persiapan}

Tahap persiapan diawali dengan pembelian $2 \mathrm{~kg}$ daging ayam dan $1 \mathrm{~kg}$ daun katuk segar di Pasar Panorama Bengkulu. Daging ayam yang digunakan dalam penelitian ini berjumlah \pm 14 potong ayam dengan berat rata-rata $100 \mathrm{gr} /$ sampelnya untuk 6 perlakuan dan membuat ekstrak daun katuk dengan cara digiling menggunakan pengilingan daging.

\section{Tahap Perendaman}

Daging ayam $100 \mathrm{~g}$ untuk setiap perlakuan, dalam tahap perendaman ini direndam selama 30 menit dan 60 menit, kecuali untuk daging ayam tanpa perlakuan konsentrasi ekstrak daun katuk. Setiap potongan daging ayam yang sudah direndam, ditiriskan dengan menggunakan wadah saringan, lalu setelah itu disimpan untuk tahapan selanjutnya.

\section{Tahap Penyimpanan}

Daging ayam yang sudah ditiriskan, kemudian disimpan dalam nampan-nampan kecil pada suhu ruang $\left(25-30{ }^{\circ} \mathrm{C}\right)$ selama 12 jam dalam keadaan terbuka. Percobaan dilakukan sebanyak tiga kali ulangan dengan selang pengamatan untuk uji, uji derajat keasaman $(\mathrm{pH})$, kadar air daging ayam dan Total Plate Count (TPC).

\section{Tahap Pengujian}

Tahap pengujian terhadap sampel dilakukan secara subyektif (sensori) dan obyektif. Pengujian secara subyektif terhadap sampel dilakukan dengan menggunakan uji organoleptik menggunakan scoresheet penilaian terhadap sampel daging ayam, sedangkan untuk pengujian obyektif menggunakan pengukuran nilai derajat keasaman $(\mathrm{pH})$, nilai kadar air dan penghitungan nilai koloni total bakteri atau Total Plate Count (TPC).

\section{Uji Organoleptik}

Pengujian organoleptik dilakukan setelah waktu 12 jam oleh 20 orang panelis tetap. Penilaian indrawi ini dilakukan terhadap beberapa parameter uji, yaitu parameter warna, aroma dan tekstur. Potongan daging ayam yang diuji secara organoleptik diberi nilai berdasarkan penilaian panelis dan dituangkan dalam lembaran scoresheet (penilaian) dalam skala 1 (satu) sebagai nilai terendah dan angka 5 (lima) sebagai nilai tertinggi.

\section{Metode Penelitian}

Metode penelitian yang digunakan dalam penelitian ini adalah Metode Rancangan Acak Lengkap (RAL) yang terdiri 
dari 2 perlakuan yaitu konsentrasi ekstrak daun katuk dan waktu perendaman. Konsentrasi ekstrak daun katuk terdiri dari $10 \%$, 20\% dan 30\% dan waktu perendaman menggunakan waktu 30 menit dan 60 menit. Untuk faktor perlakuan yang dilakukan adalah perendaman daging ayam dalam ekstrak daun katuk yang meliputi 6 faktor perlakuan yaitu :

Kontrol $=$ daging ayam tanpa perlakuan

D1T1 = daging ayam $100 \mathrm{~g}+200 \mathrm{~mL}$ aquades $+10 \%$ konsentrasi ekstrak daun katuk +30 menit

D1T2 = daging ayam $100 \mathrm{~g}+200 \mathrm{~mL}$ aquades $+10 \%$ konsentrasi ekstrak daun katuk + 60 menit

D2T1 = daging ayam $100 \mathrm{~g}+200 \mathrm{~mL}$ aquades $+20 \%$ konsentrasi ekstrak daun katuk +30 menit

$\mathrm{D} 2 \mathrm{~T} 2=$ daging ayam $100 \mathrm{~g}+200 \mathrm{~mL}$ aquades $+20 \%$ konsentrasi ekstrak daun katuk +60 menit

D3T1 = daging ayam $100 \mathrm{~g}+200 \mathrm{~mL}$ aquades $+30 \%$ konsentrasi ekstrak daun katuk + 30 menit

D3T2 = daging ayam $100 \mathrm{~g}+200 \mathrm{~mL}$ aquades $+30 \%$ konsentrasi ekstrak daun katuk +60 menit

\section{HASIL DAN PEMBAHASAN}

\section{Nilai Derajat Keasaman (pH) Daging} Ayam

Nilai derajat keasaman yang dinyatakan dengan nilai $\mathrm{pH}$ merupakan salah satu faktor penting yang menentukan ketahanan bahan pangan terhadap pembusukan yang disebabkan oleh pertumbuhan bakteri (Lawrie, 1995). Hasil analisis $\mathrm{pH}$ daging ayam perlakuan konsentrasi ekstrak daun katuk dapat dilihat pada tabel 1.

Tabel 1. menjelaskan nilai rerata analisis $\mathrm{pH}$ daging ayam yang diberi perlakuan dengan yang tidak diberi perlakuan menunjukkan perbedaan yang nyata. Semakin tinggi konsentrasi ekstrak daun katuk yang diberikan maka diikuti pula dengan kenaikan nilai $\mathrm{pH}$ daging ayam, begitu juga dengan semakin lama waktu perendaman juga diikuti oleh kenaikan nilai $\mathrm{pH}$ daging ayam. Nilai $\mathrm{pH}$ daging yang dianjurkan Standar Nasional Indonesia yaitu 5,3-6,5. Dari data di atas nilai $\mathrm{pH}$ masih menunjukkan batas yang dianjurkan. Ini menunjukkan semakin tinggi larutan ekstrak daun katuk yang diberikan maka akan menaikan nilai $\mathrm{pH}$ daging ayam. Ini sesuai dengan hasil penelitian Bambang. K, dkk (2007), dengan perlakuan konsentrasi ekstrak daun katuk 0, 10, 20, dan $30 \%$ yang hasilnya yaitu secara berturut-turut 5,35, 5,26, 5,20 dan 5,17, yang menunjukkan bahwa semakin tinggi konsentrasi ekstrak daun katuk yang diberikan, maka akan diikuti dengan kenaikan $\mathrm{pH}$ daging sapi.

Terjadinya kenaikan $\mathrm{pH}$ daging ayam disebabkan oleh konsentrasi ekstrak daun katuk dan waktu perendaman yang diberikan, karena ekstrak daun katuk mengandung senyawa asam. Muktiningsih (2006) menjelaskan bahwa didalam ekstrak daun katuk terkandung beberapa senyawa asam antra lain asam benzoat dan asam 2fenilmalonat. Muchtadi dan Sugiyono (1992) menambahkan bahwa senyawa asam seperti asam benzoat, asam laktat akan 
mengakibatkan kenaikan $\mathrm{pH}$ daging. Semakin rendahnya nilai $\mathrm{pH}$ pada suatu produk umumnya akan meningkatkan daya simpan produk, karena bakteri akan sulit hidup dalam $\mathrm{pH}$ rendah, kecuali bakteri yang tahan pada pH rendah (acidophilic) (Soeparno, 2005).

\section{Analisis Kadar Air Daging Ayam}

Hasil analisis kadar air daging ayam dengan perlakuan konsentrasi ekstrak daun katuk dapat dilihat pada tabel 2 ..

Tabel 2. menjelaskan perlakuan konsentrasi ekstrak daun katuk mampu menurunkan kadar air daging ayam. Dari data di atas kadar air terendah terdapat pada perlakuan daging ayam $100 \mathrm{~g}+200 \mathrm{~mL}$ aquades $+20 \%$ ekstrak daun katuk +30 menit yaitu $21,87 \%$ dan yang tertinggi terdapat pada perlakuan daging ayam $100 \mathrm{~g}+$ $200 \mathrm{~mL}$ aquades $+30 \%$ ekstrak daun katuk + 60 menit yaitu $31,83 \%$.

Rerata hasil analisis kadar air daging ayam pada perlakuan kontrol yaitu $(27,55 \%)$, perlakuan daging ayam $100 \mathrm{~g}+200 \mathrm{~mL}$ aquades $+10 \%$ ekstrak daun katuk +30 menit yaitu $(21,87 \%)$, perlakuan daging ayam $100 \mathrm{~g}+200 \mathrm{~mL}$ aquades $+10 \%$ ekstrak daun katuk +60 menit yaitu $(22,62 \%)$, perlakuan daging ayam $100 \mathrm{~g}+200 \mathrm{~mL}$ aquades $+20 \%$ ekstrak daun katuk + 30 menit yaitu $(22,65 \%)$, perlakuan daging ayam $100 \mathrm{~g}+200 \mathrm{~mL}$ aquades $+20 \%$ ekstrak daun katuk +60 menit yaitu $(31,83 \%)$, perlakuan daging ayam $100 \mathrm{~g}+200 \mathrm{~mL}$ aquades $+30 \%$ ekstrak daun katuk + 30 menit yaitu $(22,35 \%)$ dan perlakuan daging ayam $100 \mathrm{~g}+200 \mathrm{~mL}$ aquades $+30 \%$ ekstrak daun katuk +60 menit yaitu $(23,18 \%)$. Kadar air daging ayam menurut Standar Nasional Indonesia (SNI) yaitu $68-75 \%$. Hal sesuai dengan hasil penelitian Bambang, K, dkk (2007), dimana perlakuan konsentrasi ekstrak daun katuk 0, 10, 20 dan $30 \%$ dengan hasil sebagai berikut, $77,69 \%, 76,89 \%, 75,15 \%$ dan $73,72 \%$, ini menunjukkan semakin tinggi konsentrasi ekstrak daun katuk, maka akan menurunkan kadar air daging sapi.

Tabel 1. Pengaruh Perendaman Daging Ayam dalam Extrak Daun Katuk terhadap Kadar pH.

\begin{tabular}{|c|c|c|c|}
\hline Perlakuan & \multicolumn{3}{|c|}{ Konsentrasi Ekstrak Daun Katuk } \\
\hline Waktu Perendaman & $10 \%$ & $20 \%$ & $30 \%$ \\
\hline 30 menit & $5,8^{\mathrm{b}}$ & $5,7^{\mathrm{c}}$ & $5,4^{\mathrm{d}}$ \\
\hline 60 menit & $5,7^{\mathrm{c}}$ & $5,4^{\mathrm{d}}$ & $5,4^{\mathrm{d}}$ \\
\hline
\end{tabular}

Kontrol $=6,8^{\mathrm{a}}$

Ket : Angka yang diikuti oleh kode huruf yang berbeda menunjukan adanya perbedaan yang nyata. 
Tabel 2. Pengaruh Perendaman Daging Ayam dalam Ekstrak Daun Katuk terhadap

Kadar Air.

\begin{tabular}{|c|c|c|c|}
\hline Perlakuan & \multicolumn{3}{|c|}{ Konsentrasi Ekstrak Daun Katuk } \\
\hline Waktu Perendaman & $10 \%$ & $20 \%$ & $30 \%$ \\
\hline 30 menit & $21,87^{\mathrm{f}}$ & $22,65^{\mathrm{d}}$ & $22,35^{\mathrm{e}}$ \\
\hline 60 menit & $22,62^{\mathrm{d}}$ & $31,83^{\mathrm{a}}$ & $23,18^{\mathrm{c}}$ \\
\hline
\end{tabular}

Kontrol $=27,55^{\mathrm{b}}$

Ket : Angka yamg diikuti oleh kode huruf yang berbeda menunjukan adanya perbedaan yang nyata.

Kadar air daging ayam menurun

karena ekstrak daun katuk mengandung garam-garam mineral yang merupakan senyawa yang bersifat higroskopis yang dapat mengikat air. Kondisi ini sesuai dengan pendapat Rukmana dan Harahap (2003), bahwa ekstrak daun katuk mengandung garam-garam mineral dan mengandung senyawa asam. Ditambahkan juga oleh Fardiaz (1993) adanya solut dan ion dapat mengikat air didalam larutan atau lingkingan misalnya garam.

Kadar air yang terkandung dalam daging ayam semakin tinggi setelah dilakukan penyimpanan. Hal ini sesuai dengan Mead (1984), yang menyatakan bahwa selama postmortem, daging ayam mengalami penyusutan dan air akan dikeluarkan. Kadar air berkaitan dengan daya mengikat air dari daging ayam itu sendiri. Makin tinggi kadar air suatu produk, maka akan semakin rendah daya mengikat air produk tersebut. Hamm (1962) menyatakan bahwa kemampuan daging ayam dalam mengikat air disebabkan oleh adanya protein otot, yaitu aktomiosin yang merupakan komponen utama miofibril.

\section{Analisis TPC Daging Ayam}

Pengukuran seberapa jauh tingkat kerusakan daging, dapat dilihat dari banyaknya bakteri yang tumbuh dan berkembang pada daging tersebut dengan menggunakan salah satu metode pengukuran, yaitu pengukuran nilai TPC. Nilai TPC dapat mempengaruhi perubahan fisik pada daging. Semakin banyak kandungan bakteri, maka semakin menurun kualitas dari daging tersebut. Adapun hasil analisis TPC daging ayam dengan perlakuan konsentrasi ekstrak daun katuk dapat dilihat pada tabel 3.

Penjelasan dari tabel 3 untuk perlakuan konsentrasi ekstak daun katuk mampu menurunkan jumlah total koloni bakteri pada daging ayam. Pada perlakuan kontrol, total koloni bakteri menunjukkan angka yang paling tinggi sedangkan pada perlakuan konsentrasi ekstrak daun katuk 30\% total koloni bakteri menunjukkan angka yang paling kecil. 
Tabel 3. Pengaruh Perendaman Daging Ayam dalam Ekstrak Daun Katuk terhadap

Total Koloni Bakteri.

\begin{tabular}{|c|c|c|c|}
\hline Perlakuan & \multicolumn{3}{|c|}{ Konsentrasi Ekstrak Daun Katuk } \\
\hline Waktu Perendaman & $10 \%$ & $20 \%$ & $30 \%$ \\
\hline 30 menit & $2.666,67^{\mathrm{b}}$ & $2.000^{\mathrm{cd}}$ & $666,67^{\mathrm{e}}$ \\
\hline 60 menit & $2.333,34^{\mathrm{bc}}$ & $1.666,67^{\mathrm{d}}$ & $666,67^{\mathrm{e}}$ \\
\hline
\end{tabular}

Kontrol $=3.333,34^{\mathrm{a}}$

Ket : Angka yang diikuti oleh kode huruf yang berbeda menunjukan adanya perbedaan yang nyata.

Rerata hasil analisis nilai TPC daging ayam pada perlakuan kontrol yaitu 3.333,34 $\left(3,3 \times 10^{3} \mathrm{cfu} / \mathrm{g}\right)$, perlakuan daging ayam 100 gr $+200 \mathrm{~mL}$ aquades $+10 \%$ ekstrak daun katuk +30 menit yaitu $2.333,34\left(2,3 \times 10^{3}\right.$ cfu/g), perlakuan daging ayam $100 \mathrm{gr}+200$ $\mathrm{mL}$ aquades $+10 \%$ ekstrak daun katuk +60 menit yaitu 2.666,67 (2,6 x $\left.10^{3} \mathrm{cfu} / \mathrm{g}\right)$, perlakuan daging ayam $100 \mathrm{gr}+200 \mathrm{~mL}$ aquades $+20 \%$ ekstrak daun katuk +30 menit yaitu $2.000\left(2 \times 10^{3} \mathrm{cfu} / \mathrm{g}\right)$, perlakuan daging ayam $100 \mathrm{gr}+200 \mathrm{~mL}$ aquades +20 $\%$ ekstrak daun katuk +60 menit yaitu $1.666,67\left(1,6 \times 10^{3} \mathrm{cfu} / \mathrm{g}\right)$, perlakuan daging ayam $100 \mathrm{gr}+200 \mathrm{~mL}$ aquades $+30 \%$ ekstrak daun katuk +30 menit yaitu 666,67 (6 x $\left.10^{2} \mathrm{cfu} / \mathrm{g}\right)$, perlakuan daging ayam $100 \mathrm{gr}+$ $200 \mathrm{~mL}$ aquades $+30 \%$ ekstrak daun katuk + 60 menit yaitu 666,67 (6 x $10^{2} \quad$ cfu/g). Sedangkan batas pertumbuhan bakteri yang dianjurkan oleh Standar Nasional Indonesia yaitu $1 \times 10^{6} \mathrm{cfu} / \mathrm{g}$.

Pemberian ekstrak daun katuk memberikan pengaruh yang nyata terhadap pertumbuhan bakteri pada daging ayam. Hal ini dapat dilihat dari jumlah total koloni bakteri pada perlakuan kontrol, jumlah bakteri yang berkembang yaitu $3,3 \times 10^{3} \mathrm{cfu} / \mathrm{g}$, ini menunjukkan nilai yang paling tinggi. Sedangkan pada perlakuan daging ayam 100 gr $+200 \mathrm{~mL}$ aquades $+30 \%$ ekstrak daun katuk + 30 menit dan daging ayam $100 \mathrm{gr}+$ $200 \mathrm{~mL}$ aquades $+30 \%$ ekstrak daun katuk + 60 menit jumlah bakterinya yaitu $6 \times 10^{2}$ cfu/g, ini angka terkecil dari seluruh perlakuan. Sedangkan nilai TPC daging ayam yang dianjurkan berkisar $1 \times 10^{6}$. Terlihat bahwa penambahan ekstrak daun katuk akan terjadi penurunan total koloni bakteri. Hal ini sesuai dengan hasil penelitian Bambang, K, dkk (2007), dengan perlakuan konsentrasi ekstrak daun katuk 0, 10, 20 dan $30 \%$ dengan hasil sebagai berikut, 7,5 x 10 $, 4,3 \times 10^{5}, 3,9$ x $10^{5}$ dan $1,6 \times 10^{5}$, semakin tinggi konsentrasi ekstrak daun katuk yang diberikan, maka akan menghambat pertumbuhan bakteri pada daging sapi. Penurunan total koloni bakteri diakibatkan oleh kandungan asam dan garam-garam mineral yang terkandung didalam ekstrak daun katuk. Asam dan garam-garam mineral dapat menghambat pertumbuhan bakteri, 
sesusai dengan pendapat Lawrie (2003) yang menyatakan bahwa hampir semua microorganisme yang akan tumbuh dan berkembang biak pada daging dapat dihambat oleh asam dan garam-garam mineral.

Pertumbuhan bakteri sangat erat kaitannya dengan $\mathrm{pH}$ dan kadar air yang terdapat didalam daging ayam, semakin rendah $\mathrm{pH}$ dan kadar air yang terdapat didalam daging ayam akan menyebabkan pertumbuhan bakteri semakin terhambat, sehingga total koloni bakteri akan semakin rendah. Hal ini sesuai dengan pendapat Forrest dkk, (1975) yang menjelaskan bahwa faktor yang mempengaruhi pertumbuhan bakteri pada daging adalah $\mathrm{pH}$ dan kadar air.

\section{Uji Organoleptik}

Daging ayam, baik tanpa atau dengan perlakuan konsentrasi ekstrak daun katuk, diuji secara organoleptik setelah disimpan selama 12 jam oleh 20 orang panelis tetap. Uji organoleptik merupakan suatu metode pengujian yang dilakukan dengan panca indera dalam menilai kualitas dari suatu produk pangan. Beberapa parameter yang digunakan dalam uji organoleptik ini antara lain, warna, tekstur dan aroma.

\section{Uji Organoleptik Warna Daging Ayam}

Warna merupakan faktor penting dalam penerimaan dan penolakan produk pangan yang akan dikonsumsi dan dapat mempengaruhi kualitas sensori lainnya (Fletcher, 2006). Perubahan warna akan menunjukkan perubahan nilai gizi, sehingga perubahan warna dijadikan indikator tingkat nilai gizi maksimum yang diterima (Arpah, 2001). Hasil uji organoleptik warna pada daging ayam dengan perlakuan konsentrasi ekstrak daun katuk 10\%, 20\% dan 30\% pada penyimpanan suhu ruang selama 12 jam dapat dilihat pada tabel 4 .

Tabel 4 menjelaskan rerata uji organoleptik warna daging ayam yang memiliki nilai terendah adalah daging ayam perlakuan kontrol yaitu 1,9 (tidak suka), daging ayam berwarna pucat atau putih kekuningan dan tidak menarik, diikuti perlakuan daging ayam direndam ekstrak daun katuk $10 \mathrm{~mL}$ dengan waktu 60 menit dengan nilai tertinggi yaitu 2,2 dimana warna daging berwarna putih pucat dan tidak menarik.

Perlakuan perendaman daging ayam dalam ekstrak daun katuk dengan perbandingan konsentrasi ekstrak daun katuk $10 \%, 20 \%$ dan 30\%, menunjukkan tidak ada perbedaan nyata terhadap tingkat kesukaan warna daging ayam. Warna daging ayam yang dihasilkan yaitu berwarna putih kekuningan. Warna daging ayam yang masih segar yaitu berwarna kuning keemasan. Warna pada daging ayam juga dipengaruhi oleh lamanya waktu pengujian yaitu 12 jam setelah proses perendaman yang menimbulkan warna yang agak putih atau pucat. Warna daging ayam mengalami perubahan selama penyimpanan. Daging ayam yang terlalu lama disimpan akan semakin kusam. Hal ini sesuai dengan Baèza (2004), bahwa timbulnya perubahan warna daging ayam disebabkan adanya interaksi antara pigmen warna daging ayam dengan oksigen. 
Tabel 4. Rerata Uji Organoleptik Warna Daging Ayam

\begin{tabular}{|c|c|c|c|}
\hline Perlakuan & \multicolumn{3}{|c|}{ Konsentrasi Ekstrak Daun Katuk } \\
\hline Waktu Perendaman & $10 \%$ & $20 \%$ & $30 \%$ \\
\hline 30 menit & $2,1^{\mathrm{a}}$ & $2^{\mathrm{a}}$ & $2,05^{\mathrm{a}}$ \\
\hline 60 menit & $2,2^{\mathrm{a}}$ & $2,15^{\mathrm{a}}$ & $2^{\mathrm{a}}$ \\
\hline
\end{tabular}

Kontrol $=1,95^{\mathrm{a}}$

Ket : Angka yang diikuti oleh kode huruf yang sama menunjukan tidak adanya perbedaan yang nyata.

Skala penilaian ; 1. Sangat tidak suka ; 2. Tidak suka ; 3. Agak suka ; 4. Suka ; 5. Sangat suka.

\section{Uji Organoleptik Aroma Daging Ayam}

Hasil uji organoleptik aroma daging ayam dengan perlakuan konsentrasi ekstrak daun katuk 10\%, 20\% dan 30\% pada penyimpanan suhu ruang selama 12 jam ditampilkan pada tabel 5.

Tabel 5 menjelaskan nilai rerata uji organoleptik aroma daging ayam setelah direndam dengan ekstrak daun katuk. Penilaian tertinggi terdapat pada perlakuan kontrol dan daging ayam direndam ekstrak daun katuk $20 \%$ dengan waktu 30 menit yaitu 2,05 dan yang terkecil pada perlakuan daging ayam direndam ekstrak daun katuk $30 \%$ dengan waktu 30 menit dan 60 menit yaitu 1,75. Dimana daging ayam dari semua perlakuan menunjukkan tidak adanya perbedaan yang nyata terhadap aroma daging ayam.

Perlakuan perendaman daging ayam dalam larutan ekstrak daun katuk dengan konsentrasi ekstrak daun katuk 10\%, 20\% dan $30 \%$, menunjukkan tidak berpengaruh nyata terhadap tingkat kesukaan aroma daging ayam. Penggunaan ekstrak daun katuk dengan tidak menggunakan ekstrak daun katuk menunjukan tidak ada perbedaan terhadap nilai kesukaan aroma daging ayam. Hal ini dikarenakan daging ayam terlalu lama dilakukan penyimpanan. Aroma daging ayam sebelum dilakukan penyimpanan masih memiliki aroma yang sangat segar. Seiring dengan lamanya penyimpanan yang dilakukan, aroma daging ayam akan semakin menurun. Semakin lama daging ayam disimpan maka lambat laun aroma yang dihasilkan akan semakin busuk..

Berdasarkan Mead (2004), aroma daging ayam yang semakin menurun disebabkan oleh tingginya jumlah bakteri pada daging yang menyebabkan terurainya protein menjadi senyawa-senyawa volatil yang menghasilkan aroma busuk karena produksi sulfur, hidrogen sulfida $\left(\mathrm{H}_{2} \mathrm{~S}\right)$, amoniak $\left(\mathrm{NH}_{3}\right)$, metal merkaptan, dimetil sulfida, dan dimetil disulfida. Tingginya jumlah bakteri juga mengakibatkan degradasi lemak yang dapat merusak mutu daging ayam, salah satunya aroma daging ayam itu sendiri. Terjadinya degradasi lemak akibat 
pertumbuhan mikroba dapat membentuk aroma yang tengik atau busuk (Baèza, 2004). Aroma busuk pada bahan pangan disebabkan oleh aktifitas golongan bakteri koliform dan beberapa spesies bakteri yang bersifat putrefactive (pembuat busuk), diantaranya Clostridium dan Pseudomonas (Frazier dan Westhoff, 1978).

\section{Uji Organoleptik Tekstur Daging Ayam}

Hasil uji organoleptik tekstur daging ayam dengan perlakuan konsentrasi ekstrak daun katuk 10\%, 20\% dan 30\% pada penyimpanan suhu ruang selama 12 jam ditampilkan pada tabel 6 .

Tabel 6 menjelaskan rerata uji organoleptik tekstur daging ayam, dimana perlakuan kontrol dengan konsentrasi ekstrak daun katuk 10\%, 20\% dan 30\% menunjukkan tidak adanya perbedaan yang nyata terhadap tingkat kesukaan tekstur daging ayam. Perlakuan perendaman daging ayam dalam ekstrak daun katuk dengan konsentrasi 10\%, $20 \%$ dan $30 \%$ menunjukkan tidak adanya perbedaan yang nyata terhadap tekstur daging ayam. Hal ini disebabkan karena semakin lama penyimpanan yang dilakukan akan menyebabkan kadar air pada bahan pangan juga semakin meningkat (Winarno, 1997) sehingga menyebabkan tekstur bahan pangan semakin lembek. Tekstur daging ayam sebelum dilakukan proses penyimpanan masih dalam keadaan padat dan elastis jika ditekan jari. Seiring dengan lamanya penyimpanan, tekstur daging ayam semakin menurun, yaitu menjadi semakin lunak dan tidak lagi elastis seperti awal penyimpanan.

Tingginya kadar air daging ayam dapat menyebabkan semakin tingginya pertumbuhan dan perkembangan bakteri, serta degradasi protein yang dapat mengakibatkan pelepasan air pada daging, meningkat (Winarno, 1997), sehingga terjadi perubahan fisik berupa menurunnya tingkat konsistensi suatu bahan pangan, yang ditandai dengan semakin lunak dan berairnya bahan pangan tersebut.

Tabel 5. Rerata Uji Organoleptik Aroma Daging Ayam

\begin{tabular}{|c|c|c|c|}
\hline Perlakuan & \multicolumn{3}{|c|}{ Konsentrasi Ekstrak Daun Katuk } \\
\hline Waktu Perendaman & $10 \%$ & $20 \%$ & $30 \%$ \\
\hline 30 menit & $2,05^{\mathrm{a}}$ & $2^{\mathrm{a}}$ & $1,75^{\mathrm{a}}$ \\
\hline 60 menit & $1,8^{\mathrm{a}}$ & $1,85^{\mathrm{a}}$ & $1,75^{\mathrm{a}}$ \\
\hline
\end{tabular}

Kontrol $=2,05^{\mathrm{a}}$

Ket : Angka yang diikuti oleh kode huruf yang sama menunjukan tidak adanya perbedaan yang nyata.

Skala penilaian ; 1. Sangat tidak suka ; 2. Tidak suka ; 3. Agak suka ; 4. Suka ; 5. Sangat suka. 
Tabel 6. Rerata Uji Organoleptik Tekstur Daging Ayam

\begin{tabular}{|c|c|c|c|}
\hline perlakuan & \multicolumn{3}{|c|}{ Konsentrasi ekstrak daun katuk } \\
\hline waktu perendaman & $10 \%$ & $20 \%$ & $30 \%$ \\
\hline 30 menit & $2^{\mathrm{a}}$ & $2,25^{\mathrm{a}}$ & $2,15^{\mathrm{a}}$ \\
\hline 60 menit & $2,05^{\mathrm{a}}$ & $2,2^{\mathrm{a}}$ & $2,1^{\mathrm{a}}$ \\
\hline
\end{tabular}

Kontrol $=2^{\mathrm{a}}$

Ket : Angka yamg diikuti oleh kode huruf yang sama menunjukan tidak adanya perbedaan yang nyata.

Skala penilaian ; 1. Sangat tidak suka ; 2. Tidak suka ; 3. Agak suka ; 4. Suka ; 5. Sangat suka.

\section{KESIMPULAN}

1. Berdasarkan hasil analisis $\mathrm{pH}$, kadar air dan TPC daging ayam dengan perlakuan konsentrasi ekstrak daun katuk 10\%, 20\%, dan 30\% dan disimpan pada suhu ruang selama 12 jam, menunjukkan adanya perbedaan yang nyata terhadap daging ayam. Pemberian perlakuan konsenrasi ekstrak daun katuk pada daging ayam, mampu menurunkan angka $\mathrm{pH}$, kadar air dan TPC pada daging ayam. Konsentrasi larutan ekstrak daun katuk yang paling optimal yaitu $30 \%$ dengan lama perendaman 30 menit ke dalam ekstrak daun katuk dengan nilai $\mathrm{pH}$ 5,4, kadar air 22,35\% dan TPC $6 \times 10^{2} \mathrm{cfu} / \mathrm{g}$.

2. Berdasarkan hasil uji organoleptik terhadap warna, aroma dan tekstur pada daging ayam dengan perlakuan konsentrasi ekstrak daun katuk 10\%, $20 \%$ dan $30 \%$ dan disimpan pada suhu ruang selama 12 jam, menunjukkan tidak adanya perbedaan yang nyata. Perlakuan konsentrasi ekstrak daun katuk, tidak memberikan pengaruh terhadap tingkat kesukaan terhadap nilai uji sensori dengan parameter warna, aroma dan tekstur pada daging ayam.

\section{DAFTAR PUSTAKA}

Arpah. 2001. Penetapan Kadaluarsa Pangan. Departemen Ilmu dan Teknologi Pangan Institut Pertanian Bogor. Bogor.

Bambang K, Irdha M, Triani A, 2007. Penggunaan Ekstrak Daun Katuk Sebagai Bahan Pengawet Alami Daging Sapi Segar. Universitas Riau. Pekanbaru.

Cahyadi, W. 2009. Bahan Tambahan Pangan. Bumi Aksara. Jakarta.

Forrest JC, ED Alberle, HB Hendrick, MD Judge, RA Markel. 1975. Principle of Meat Science. WH Feeman Co. San Fransisco.

Frazier WC, DC Westhoff. 1978. Food microbiology. 3rd Edition. Hill Publishing Company Limited. New Delhi.

Lawrie RA. 2003. Ilmu Daging. UI Press, Terjemahan dari Meat Science. Jakarta.

Murtidjo BA. 2003. Pemotongan dan penanganan daging ayam. Kanisius. Jakarta.

Rahardjo AHD, Santosa BS. 2005. Kajian terhadap kualitas karkas broiler yang disimpan pada suhu kamar setelah perlakuan pengukusan. Journal of Animal Production, Vol 7, No.(1): 1-5. Jakarta. 
Rukmana R, Harahap M. 2003. Katuk Potensi dan Manfaatnya. KaniSius. Yogyakarta.

Simonsen B, Hamm R, Rogowski B. 1988. Meat as food. Dalam Meat Science, Milk Science, and Technology. Cross HR dan AJ Overby (Ed). Elsevier
Science Publisher BV. Amsterdam, The Netherlands.

Soeparno. 1994. Ilmu dan Teknologi Daging. Gadjah Mada University Press. Yogyakarta.

Widianti, E. 2011. Bahan Pengawet. Bahanajar Kimia. Jakarta. 